\title{
PENERAPAN TEORI STRUKTUR CERITA PADA PEMBUATAN FILM
}

\author{
Angela Oscario \\ Jurusan Desain Komunikasi Visual, School of Design, BINUS University \\ Jln. K.H. Syahdan No. 9, Palmerah, Jakarta Barat 11480 \\ oscario_box@yahoo.com
}

\begin{abstract}
Since it was created in $19^{\text {th }}$ century, film has been developed into one important communication media. The successful of communication depends on how the story was told; therefore many story structure theories were created. Unfortunately, those theories are rarely applied. Literature and field studies were performed to delve deeper in story structure theories and their implementations, starts from 3 acts structure, 8 sequences structures, and hero's journey. Based on observation, these theories have been used in many box office films. Those theories are flexible, not strict formulas more likely the guidance maps to compose story. Structure story theories are the frameworks. But the content in the framework depends on each individual's creativity. Therefore, using those theories won't make our story generic. Story structure theories are tools to provoke, encourage, boost, and develop creativity. By implementing various structure story theories, film industries are expected to produce films with high-quality story that can be better in conveying any particular, messages.
\end{abstract}

Keywords: theory, the structure of story, film, communication

\begin{abstract}
ABSTRAK
Sejak diciptakan pertama kali pada abad 19, film berkembang menjadi salah satu media komunikasi yang penting. Melalui film, beragam pesan dalam berbagai bidang dapat dikomunikasikan untuk menimbulkan kepedulian, bahkan menggerakkan masyarakat. Keberhasilan komunikasi sebuah pesan sangat tergantung pada cara penyampaian cerita. Oleh sebab itu untuk membantu penyusunan sebuah cerita, diciptakan berbagai teori struktur cerita. Sayangnya, sering kali muncul keengganan untuk menerapkan teori struktur cerita. Teori-teori itu dianggap mengekang kreativitas, bahkan mematikan originalitas sebuah karya. Studi literatur dan studi lapangan dilakukan guna mendalami teori-teori struktur cerita dan penerapannya, mulai dari teori struktur cerita klasik 3 babak, 8 sekuen, hingga hero's journey. Berdasarkan pengamatan teori-teori ini telah dipercaya dan digunakan untuk merancang struktur cerita berbagai film box office. Bukannya mengekang, teori struktur cerita justru membantu menyusun cerita yang dinamis, dramatis, dan lebih fokus terhadap pesan yang ingin dikomunikasikan. Teori struktur cerita bukanlah formula baku melainkan peta panduan untuk menyusun cerita. Teori struktur cerita menyerupai sebuah kerangka, di mana untuk mengisi kerangka tersebut sangat tergantung pada kreativitas tiap individu. Oleh sebab itu teori struktur cerita tidak menghasilkan cerita yang generik. Teori struktur cerita justru merupakan alat bantu untuk memancing, mendorong, mengolah dan mengarahkan kreativitas. Dengan penerapan teori struktur cerita, diharapkan industri perfilman dapat menghasilkan film yang kuat secara cerita dan dapat mengkomunikasikan pesan dengan lebih baik, dan menarik.
\end{abstract}

Kata kunci: teori, struktur cerita, film, komunikasi 


\section{PENDAHULUAN}

Tahun demi tahun media komunikasi berkembang seiring kemajuan teknologi. Film yang berkembang semenjak abad 19, mengukuhkan diri sebagai salah satu media komunikasi yang penting, dan diminati. Berbagai pesan mulai dari kemanusiaan, moral, politik, hingga lingkungan hidup dapat dikomunikasikan secara menarik, terselubung dan tidak berkesan menggurui. Bahkan di abad 21 film mempengaruhi perkembangan teknologi, politik, dan seni. Sebuah film bukan hanya gambar yang bergerak, melainkan media yang dapat mengajak masyarakat berpikir, menggerakkan hati dan memicu tindakan nyata.

Film muncul karena adanya kegelisahan masyarakat terhadap lingkungan sekitarnya. Masalah yang ingin diangkat dan disampaikan ke tengah khalayak luaslah yang membentuk janin sebuah film. Namun film baru akan dilahirkan jika masalah itu dikemas dalam jalinan cerita terstruktur. Struktur cerita dalam film bagaikan tulang punggung yang menopang seluruh tubuh makhluk hidup. Struktur cerita yang dinamis menentukan apakah penonton bertahan menyaksikan film hingga akhir. Struktur cerita juga berperan menentukan apakah pesan yang ingin dikomunikasikan dapat tersampaikan atau tidak.

Mengingat betapa pentingnya struktur cerita, tokoh-tokoh perfilman telah menciptakan berbagai teori struktur cerita film. Beberapa teori yang terkenal antara lain teori klasik 3 babak yang dijabarkan oleh Field (1984), 8 sekuen dan hero's journey yang dijabarkan oleh Campbell (2008). Teori-teori ini telah dipercaya dan digunakan untuk merancang struktur cerita berbagai film box office.

Sayangnya, terkadang muncul keengganan untuk menerapkan teori struktur cerita. Teori ini dianggap mengekang kreativitas, bahkan mematikan originalitas sebuah karya. Namun benarkah demikian? Apakah film-film yang menerapkan teori-teori struktur cerita sama sekali tidak original dan tidak kreatif? Dengan adanya penulisan ini diharapkan pandangan negatif terhadap teori struktur cerita film dapat berkurang.

\section{METODE}

Penelitian yang dilakukan untuk mengetahui penerapan berbagai teori struktur cerita pada pembuatan film ini dilakukan berdasarkan studi literatur dan studi lapangan. Pertama-tama penulis melakukan pendekatan studi kaji, dengan menghadiri workshop, melihat pengalaman dan pengamatan pribadi penulis di lingkungan kerja. Selain itu penulis melakukan studi literatur, dengan mencari berbagai sumber terkait proses mendesain struktur cerita film melalui media cetak, maupun elektronik. Sumber informasi diseleksi, dievaluasi, dan dijadikan pendukung dalam penulisan ini.

\section{HASIL DAN PEMBAHASAN}

Teori struktur cerita klasik yang terus dipakai, dan menjadi dasar perancangan berbagai teori struktur cerita lain adalah teori 3 babak atau struktur cerita dramatis (Field, 1984). Teori 3 babak atau struktur cerita dramatis adalah sebagai berikut. 


\begin{tabular}{c|c|c}
$\begin{array}{c}\text { Babak 1 } \\
\text { Awal }\end{array}$ & $\begin{array}{c}\text { Babak 2 } \\
\text { Tengah }\end{array}$ & $\begin{array}{c}\text { Babak 3 } \\
\text { Akhir }\end{array}$ \\
$\begin{array}{c}\text { Pengenalan rutinitas } \\
\text { dan karakter } \\
\text { (15\% dari keseluruhan cerita) })\end{array}$ & $\begin{array}{c}\text { Cara karakter } \\
\text { menyelesaikan masalah } \\
(70 \% \text { dari keseluruhan cerita })\end{array}$ & $\begin{array}{c}\text { Penyelesaian masalah } \\
(15 \% \text { dari keseluruhan cerita })\end{array}$ \\
Plot point 1 & Plot point 2 \\
masalah \\
dan \\
keputusan karakter \\
yang mengubah rutinitasnya
\end{tabular}

Teori 3 babak merupakan struktur cerita paling sederhana. Teori ini mengadaptasi filosofi hidup bahwa dalam kehidupan selalu ada awal, tengah dan akhir.

Berdasarkan Teori 3 babak, telah dikembangkan teori struktur cerita lain yang lebih kompleks. Salah satu teori yang terkenal adalah 8 sekuen. 8 sekuen adalah struktur cerita yang terdiri dari 8 kerangka peristiwa dan 5 titik yang mengubah alur cerita.

Teori 8 sekuens yaitu (1) Sekuen 1: pengenalan karakter dan rutinitasnya, point of attact: timbulnya masalah yang mengganggu rutinitas; (2) Sekuen 2: kehidupan karakter setelah rutinitasnya terganggu. Biasanya terjadi penyangkalan dan muncul tekad mengatasi masalah. Plot point 1: karakter mengambil keputusan untuk menyelesaikan masalah; (3) Sekuen 3: karakter mengambil tindakan paling sederhana untuk menyelesaikan masalah; (4) Sekuen 4: cara yang ia tempuh gagal dan malah memperumit masalah. Mid point: karakter sudah tidak dapat mundur lagi. Mau tidak mau ia harus menyelesaikan masalahnya; (5) Sekuen 5: saat-saat tenang atau romance; (6) Sekuen 6: karakter menemukan cara penyelesaian masalah yang jitu. Plot point 2: titik terendah karakter di mana ia harus menghadapi akibat dari keputusannya; (7) Sekuen 7: masalah seolah sudah terselesaikan, namun ternyata tidak. Terjadi pertentangan antara want dan need yang berujung pada resolusi yang salah (kebalikan dari sekuen 8). Twist : kejadian yang mengubah resolusi yang salah menjadi resolusi yang benar; (8) Sekuen 8: karakter dapat menemukan resolusi yang benar dan membuatnya bahagia.

Teori lain yang cukup terkenal dan banyak dipakai adalah teori Hero's Journey oleh Joseph Campbell. Teori yang terbagi menjadi 12 babak ini menjabarkan struktur cerita perjalanan/petualangan seorang karakter. Secara ringkas teori hero's journey dapat dijabarkan sebagai: (1) dunia rutinitas sang hero yang tidak menyenangkan, dan penuh masalah; (2) sang hero menginginkan perubahan, baik karena penyebab eksternal maupun internal; (3) sang hero takut menghadapi petualangan yang ada di hadapannya, dan berusaha mundur. Ketakutan itu muncul karena faktor eksternal, ada karakter yang mempengaruhi dan menunjukkan bahaya dalam petualangan itu, maupun dari faktor internal; (4) sang hero berjumpa dengan seseorang atau menemukan benda atau mengalami peristiwa yang membantu, memberikan nasihat, mempersenjatai atau memberi kebijaksanaan dan keberanian; (5) sang hero meninggalkan dunia lamanya dan memasuki dunia petualangan yang serba tak pasti; (6) sang hero mengalami ujian di dunia baru itu; (7) sang hero dan sekutu barunya bersiap menghadapi tantangan terberat di dunia itu; (8) sang hero berjuang, mempertaruhkan seluruh kehidupannya, dan menghadapi ketakutan terbesarnya; (9) sang hero mendapatkan sesuatu yang berharga karena berhasil menghadapi tantangan; (10) misi terselesaikan. Sang hero dengan sesuatu berharga yang ditemukannya akan kembali ke kehidupan semula; (11) sang hero menghadapi ujian sekali lagi, dan berhasil melaluinya. Karena ujian itu, ia seakan dilahirkan menjadi diri yang baru; (12) sang hero yang telah lahir baru kembali ke kehidupan semula atau melanjutkan perjuangannya. 


\section{Analisis Struktur Cerita Film UP}

Contoh penerapan teori-teori struktur cerita adalah sebagai berikut. Yang pertama adalah penerapan teori tiga babak. Hampir seluruh cerita pada dasarnya menggunakan teori tiga babak. Inilah penerapan teori 3 babak dalam film UP.

\section{Babak 1}

(Awal: pengenalan rutinitas dan karakter) Gambar 1.

Carl yang kesepian karena ditinggal Ellie, istrinya dan diancam penggusuran, seperti pada
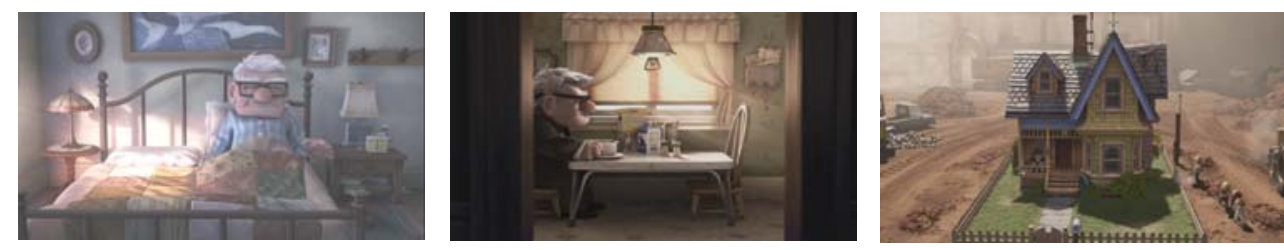

Gambar 1 Pengenalan Carl

Plot point 1: Untuk memenuhi impian Ellie dan menghindari dikirim ke panti jompo, Carl memutuskan terbang dengan rumah balonnya.
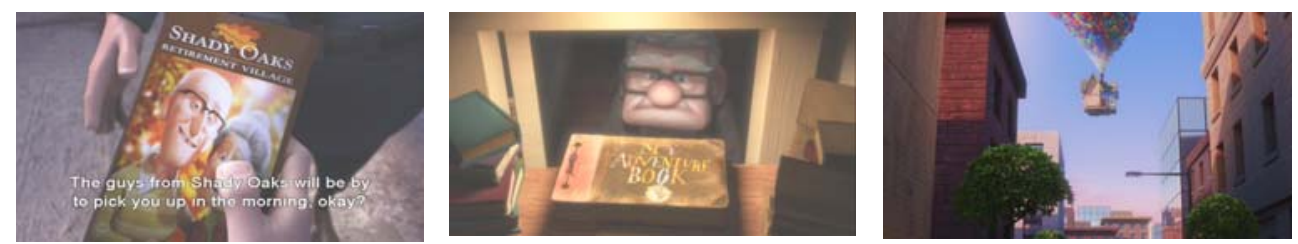

Gambar 2 Carl dengan tawaran panti jompo dan rumah balon

\section{Babak 2}

(Tengah: cara karakter mengatasi masalah dan menggapai tujuannya)

Perjalanan Carl ditemani Russel—anak laki-laki yang tidak sengaja terbawa dalam petuangan-menuju air terjun. Dalam perjalanan itu berbagai rintangan ia temui termasuk menyelamatkan Kevin, burung langka yang diburu. Ia berjuang menyelamatkan Kevin namun pada akhirnya Kevin tertangkap. Rangkaian gambar terdapat pada Gambar 3.
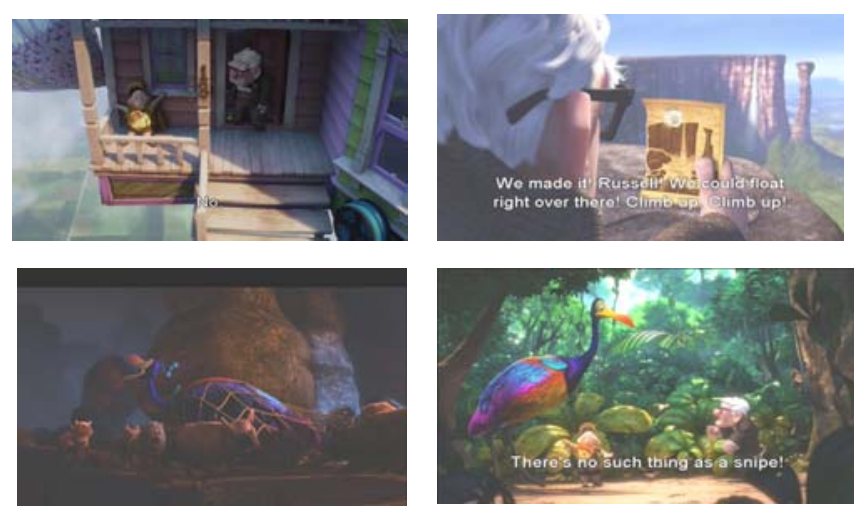

Gambar 3 Rangkaian gambar Babak 2 
Plot point 2:

Carl berhasil sampai di atas air terjun. Impian Ellie terpenuhi, namun ia merasa hampa.
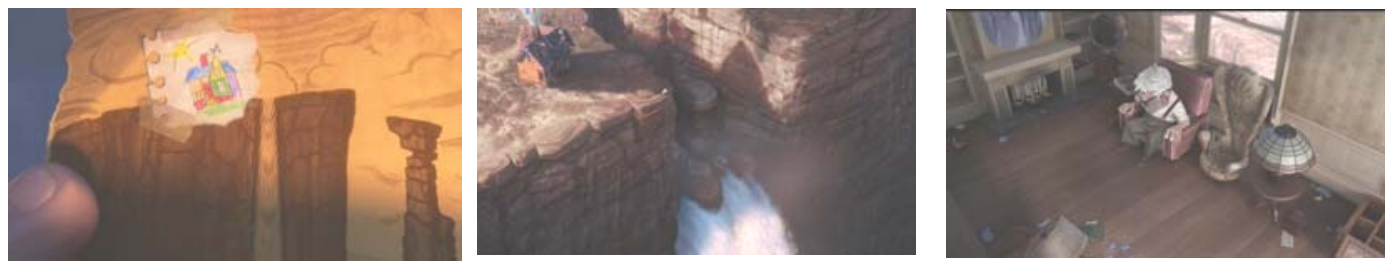

Gambar 4 Carl berhasil mencapai air terjun

\section{Babak 3}

(Akhir: penyelesaian masalah)

Carl memutuskan mengejar impiannya yang baru, dan menyelesaikan semua masalah (menyelamatkan Kevin dan Russel), seperti pada Gambar 5.
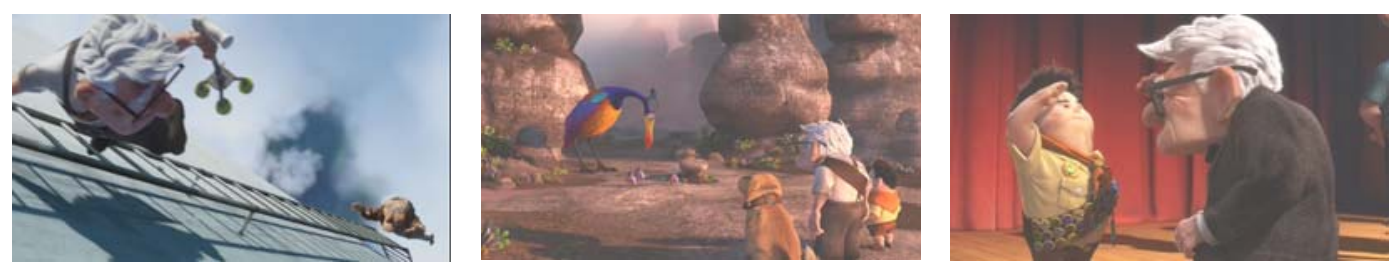

Gambar 5 Carl menyelamatkan Kevin dan Russel

Yang kedua adalah contoh penerapan teori 8 sekuens. Bisa dilihat dari contoh di bawah bahwa sebenarnya teori 8 sekuens hanyalah penjabaran lebih detail dari teori 3 babak. Berikut penerapannya dalam film UP.

Sekuen 1: perkenalan karakter dan rutinitasnya

Carl yang kesepian karena ditinggal meninggal Ellie, istrinya, dan diancam penggusuran (seperti pada Gambar 1). Dalam sekuen ini, point of attact yang terjadi adalah timbulnya masalah atau sesuatu yang mengganggu rutinitas. Tidak sengaja Carl memukul pekerja bangunan, dan akan dikirim ke panti jompo.
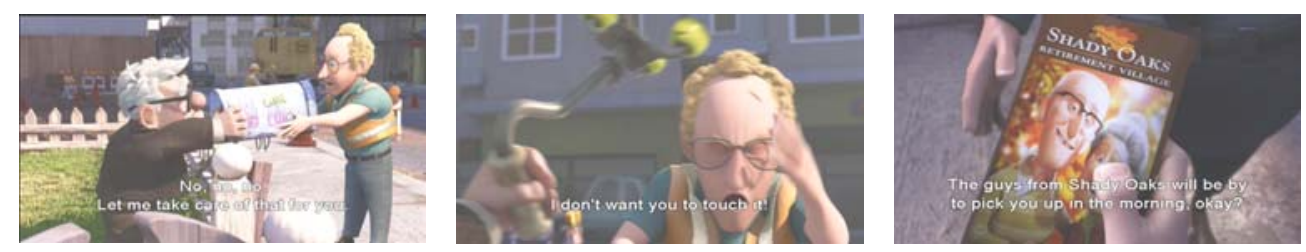

Gambar 6 Carl terlibat masalah dan akan dikirim ke panti jompo

Sekuen 2: kehidupan karakter setelah rutinitasnya terganggu, biasanya terjadi penyangkalan dan muncul tekad mengatasi masalah. Carl mengamati album kenangannya bersama Ellie. Ia teringat akan mimpi Ellie. 

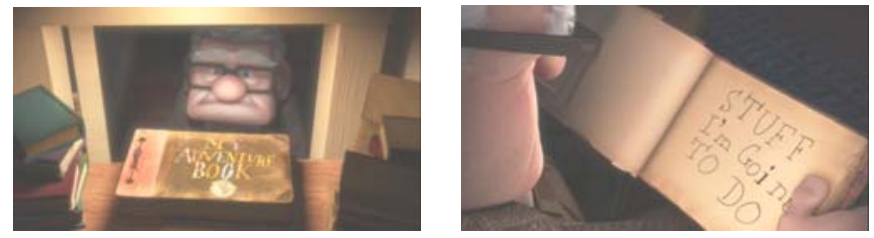

Gambar 7 Carl dan buku kenangan Ellie

Plot point 1: karakter mengambil keputusan untuk menyelesaikan masalah Carl memutuskan terbang naik rumah balon menuju paradise fall untuk meraih impian lama Ellie.

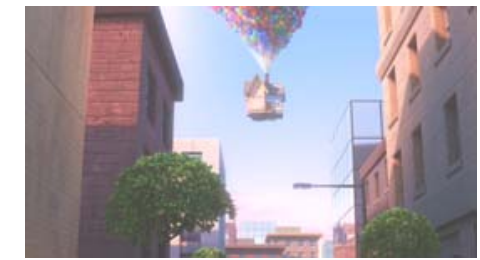

Gambar 8 Carl menerbangkan rumahnya

Sekuen 3: karakter mengambil tindakan paling sederhana untuk menyelesaikan masalah

Perjalanan di udara mengalami berbagai rintangan, hingga akhirnya mereka terdampar di suatu tempat. Ternyata Paradise Falls sudah ada di depan mata. Namun Carl dan Russel—anak laki-laki yang tidak sengaja terbawa dalam petualangan itu—tidak dapat terbang dalam rumah balon lagi.


Gambar 9 Carl dan Russel dalam perjalanan menuju Paradise Fall

Sekuen 4: cara yang ia tempuh gagal dan malah memperumit masalah.

Carl dan Russel memutuskan berjalan menuju Paradise Falls. Ketika berjalan kaki, Carl dan Russel bertemu Kevin, burung langka, dan Doug, anjing milik pemburu.


Gambar 10 Mid point 
Mid point: karakter tidak dapat mndur lagi. Mau tidak mau ia harus menyelesaikan masalah. Ternyata Kevin sedang diburu. Carl dan Russel berusaha menyelamatkan Kevin dari pemburu dan mengantarkan Kevin kembali pada anak-anaknya.
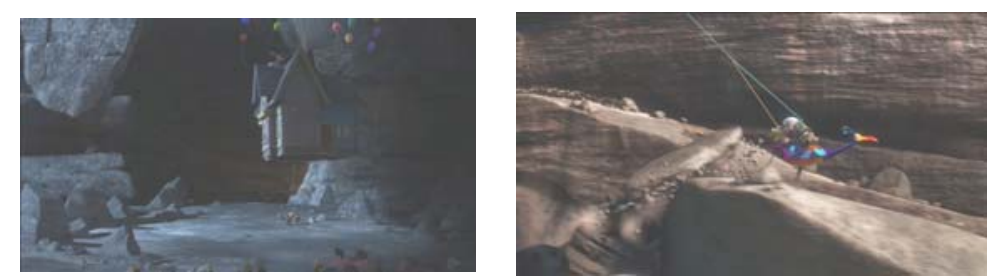

Gambar 11 Bagian romance, saat-saat tenang

Sekuen 5: bagian romance; saat-saat tenang anak-anaknya.

Perjalanan malam hari Carl, Russel, Doug, mengantarkan Kevin yang terluka kembali ke
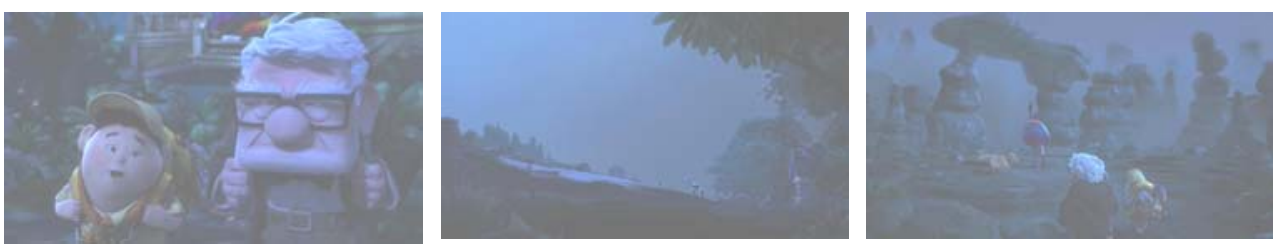

Gambar 12 Situasi penyelesaian masalah

Sekuen 6: karakter menemukan cara penyelesaian masalah yang jitu. Kevin tertangkap. Namun Carl memutuskan tidak mempedulikan Kevin dan melanjutkan meraih impian Ellie.
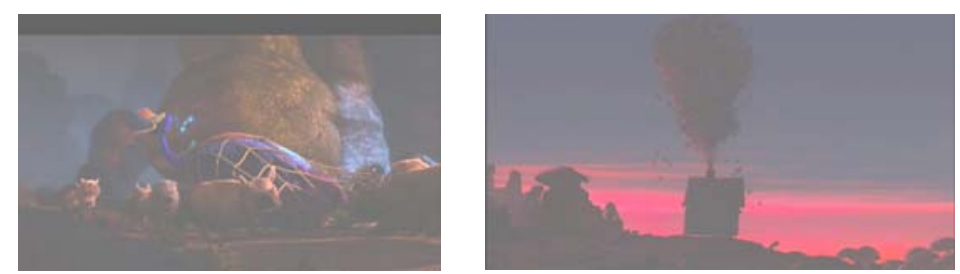

Gambar 13 Carl mencapai akhir putusan

Plot poin 2: titik di mana karakter menghadapi akibat dari keputusannya.
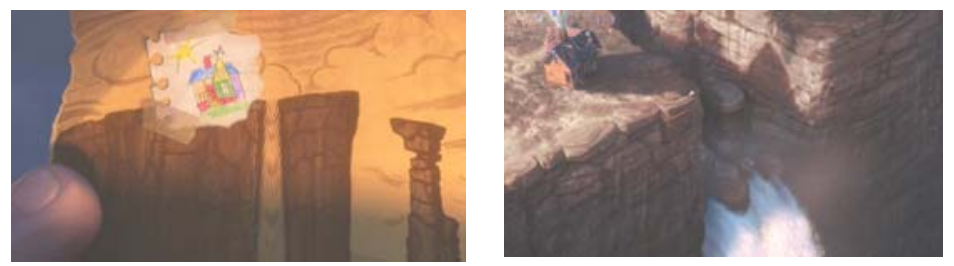

Gambar 14 Carl sampai ke Paradise Falls. Impian Ellie berhasil tercapai.

Sekuen 7: Masalah seakan sudah terselesaikan, namun ternyata tidak. Terjadi pertentangan antara want dan need yang berujung pada resolusi yang salah (kebalikan dari sekuen 8). Ternyata ketika impian itu telah tercapai, Carl tidak merasa bahagia dan tidak tahu lagi apa yang harus dilakukannya. 
Twist: kejadian yang mengubah resolusi yang salah menjadi resolusi yang benar.

Carl melihat pesan Ellie di buku kenangan untuk memulai petualangan baru. Russel pun pergi untuk menyelamatkan Kevin. Kedua hal ini memicu Carl mengambil keputusan yang tidak disangka.
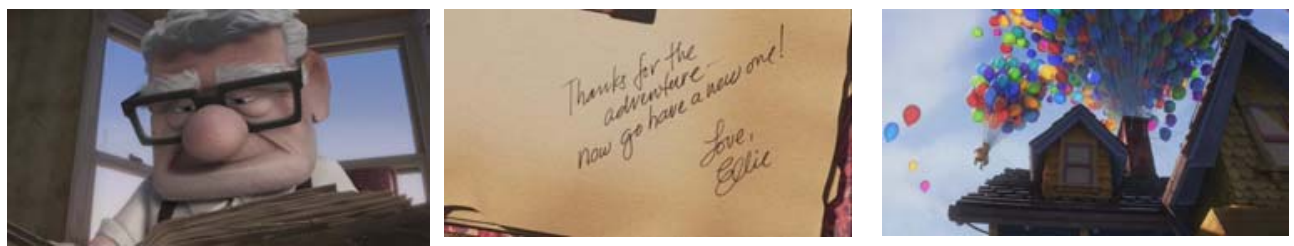

Gambar 15 Carl menemukan buku kenangan Ellie

Sekuen 8: karakter dapat menemukan resolusi yang benar dan membuatnya bahagia.

Bagian ini merupakan jawaban dari premis. Carl memutuskan meninggalkan Paradise Falls dan memulai petualangan barunya (Gambar 16). Ia dan Doug mengejar Russel dan berjuang menyelamatkan Kevin. Kevin dapat terselamatkan. Akhirnya Carl memulai hidup barunya yang tidak lagi sepi bersama Russel dan Doug.
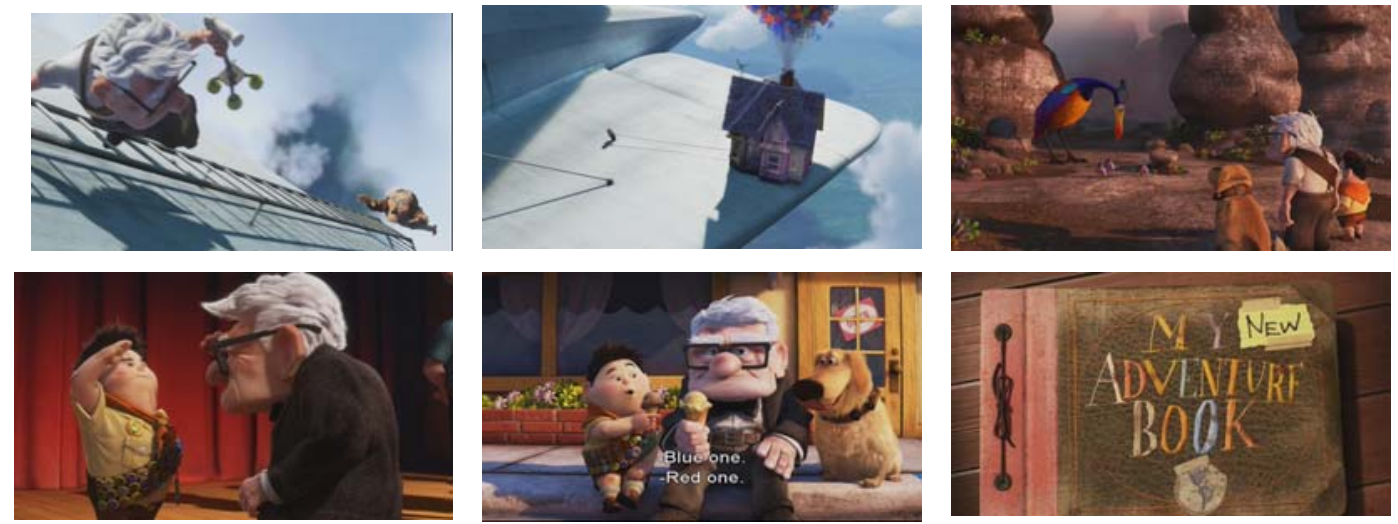

Gambar 16 Carl memulai hidup baru

Beberapa contoh film lain yang menggunakan teori 8 sekuen adalah Finding Nemo dan Ants. Walaupun menggunakan teori struktur cerita yang sama, masing-masing punya keunikan sendiri, dan bahkan di mata awam tidak tampak persamaan di antara ketiganya. Struktur cerita hanyalah membantu agar cerita dapat dibangun secara dinamis, dapat mempermainkan emosi penonton. Alice in Wonderland adalah contoh penerapan hero's journey.

Dunia rutinitas sang hero yang tidak menyenangkan, dan penuh masalah. Alice tidak suka pada kehidupan yang selalu menuntutnya tampil sebagai wanita terhormat dan melakukan apa yang dianggap baik di masyarakat. Tapi demi ibu dan orang-orang disekitarnya ia memenuhi tuntutan itu. Ia tidak berani menjadi dirinya sendiri.
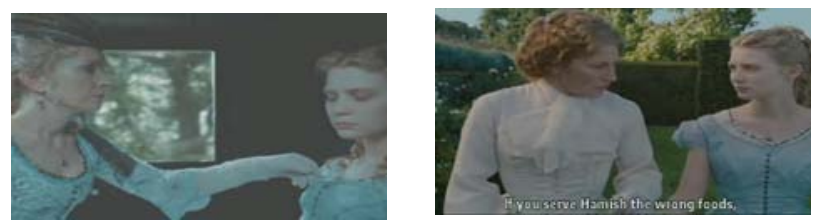

Gambar 17 Alice dan kehidupannya 
Sang hero menginginkan perubahan baik karena penyebab eksternal maupun internal. Alice dilamar seorang pria kaya. Hatinya berkata tidak, tapi semua orang menuntutnya berkata iya. Alice tidak sanggup memberikan jawaban, ia pun kabur dan masuk ke dalam dunia Wonderland.

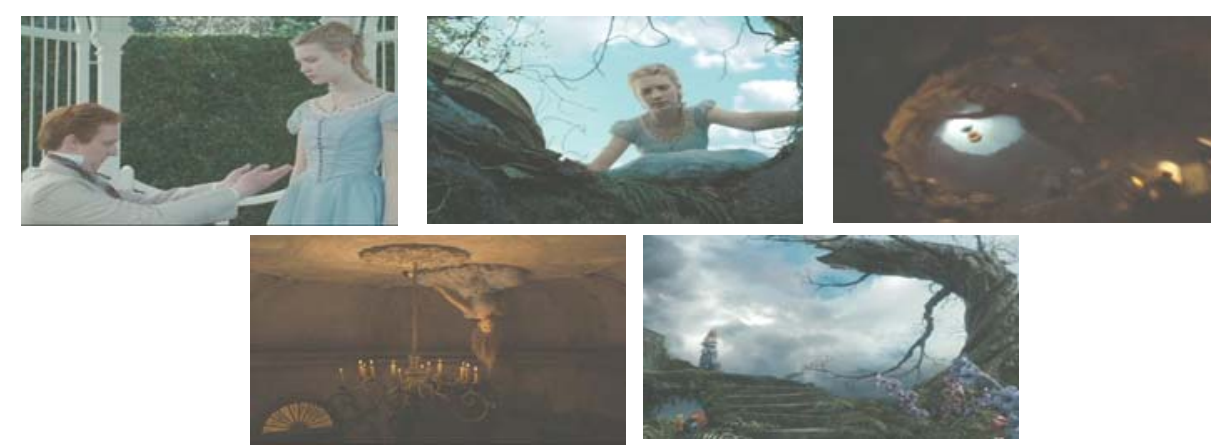

Gambar 18 Alice masuk ke dalam dunia Wonderland

Sang hero takut menghadapi petualangan yang ada di depannya, dan berusaha mundur. Dalam film ini ketakutan Alice berasal dari faktor internal yaitu Alice menyangkal bahwa dirinya adalah Alice yang tepat, yang makhluk-makhluk Wonderland cari, dan ditambah faktor eksternal, serangan dari makluk menyeramkan.
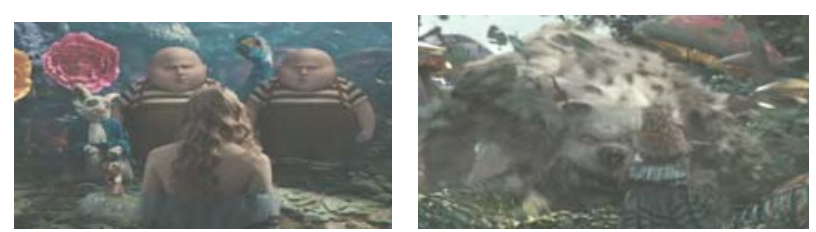

Gambar 19 Alice bertemu dengan makhluk menyeramkan

Sang hero berjumpa dengan seseorang atau menemukan benda atau mengalami peristiwa yang membantu, memberikan nasihat, mempersenjatai atau memberi kebijaksanaan dan keberanian. Alice bertemu makhluk-makhluk Wonderland yang membimbing jalannya.


Gambar 20 Makhluk menyeramkan membimbing jalan Alice

Sang hero meninggalkan dunia lamanya dan memasuki dunia petualangan yang serba tak pasti. Mau tidak mau Alice memulai petualangan untuk keluar dari dunia Wonderland. Ia harus mencari vorpal sword, bersekutu dengan White Queen dan berjuang mengalahkan Red Queen. Untuk itu ia rela menjadi tawanan Red Queen. 

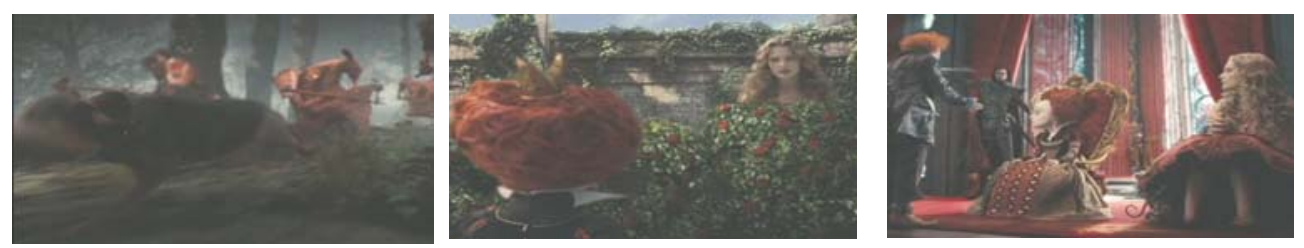

Gambar 21 Red queen

Sang hero mengalami ujian di dunia baru itu. Alice berusaha mencari vorpal swords dibantu makhluk-makhluk Wonderland. Ia berhasil mendapatkan pedang itu. Dengan bantuan makhukmakhluk Wonderland Alice kabur dari istana Red Queen dan memberikan vorpal sword pada White Queen.
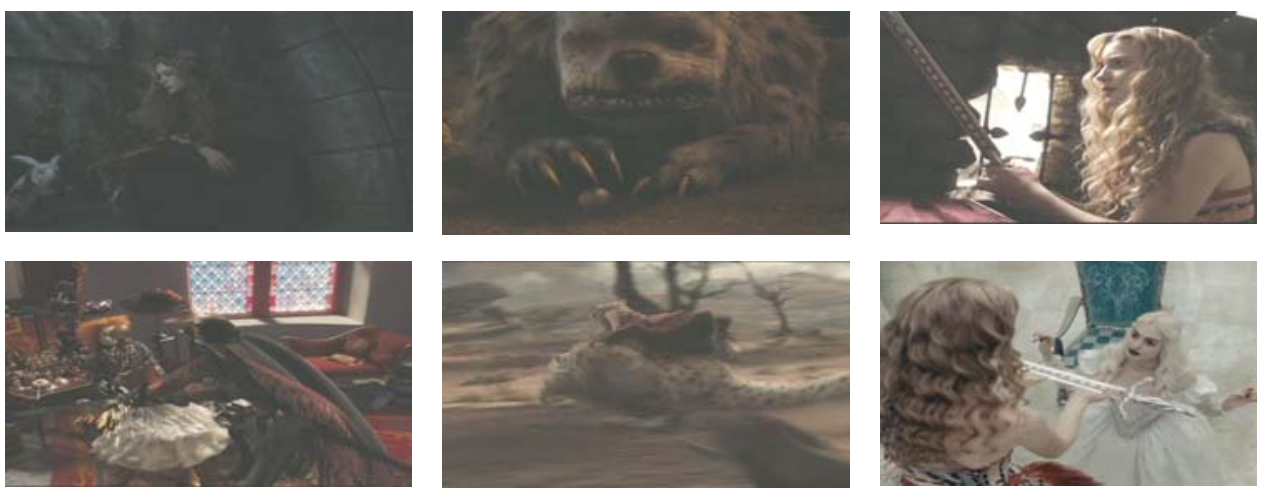

Gambar 22 White queen

Sang hero dan sekutu barunya bersiap menghadapi tantangan terberat di dunia itu. Mad Hatter dan makhluk Wonderland berhasil dibebaskan. Alice mempersiapkan pertempuran terakhir bersama White Queen. Alice harus menerima kenyataan bahwa ialah sang ksatria terpilih.
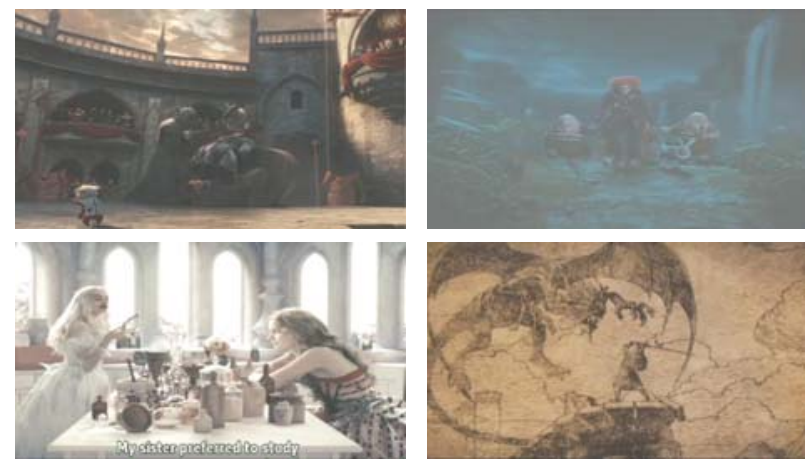

Gambar 23 Alice mempersiapkan pertempuran terakhir

Sang hero berjuang, mempertaruhkan seluruh kehidupannya, menghadapi ketakutan terbesarnya. Pertarungan terakhir antara White Queen dan Red Queen: Alice bertempur hidup dan mati melawan naga. 

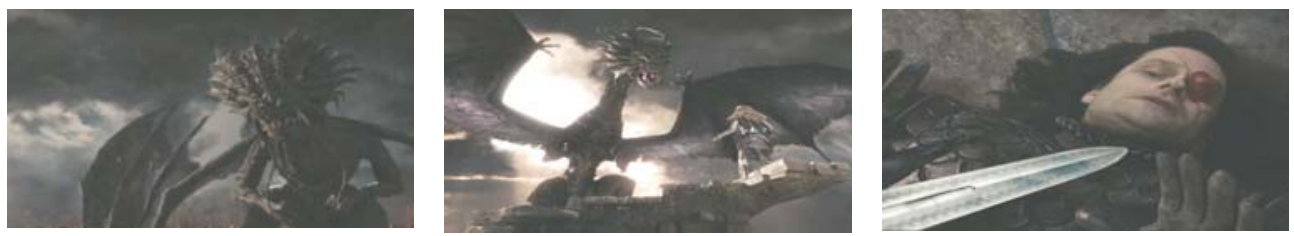

Gambar 24 Pertempuran terakhir

Sang hero mendapatkan sesuatu yang berharga karena berhasil menghadapi tantangan. Alice memenangkan pertempuran. Negeri Wonderland kembali jatuh ke tangan White Queen, sang ratu kebaikan. Alice mendapatkan ramuan untuk kembali ke dunia nyata. Tapi lebih dari itu, petualangan ini membuatnya menemukan keberanian dan jati dirinya.
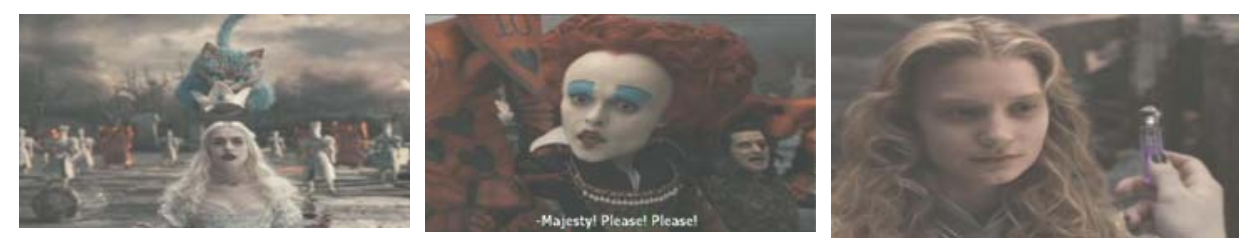

Gambar 25 Misi Alice selesai

Misi sang hero sudah terselesaikan. Sang hero dengan sesuatu berharga yang ditemukannya akan kembali ke kehidupan semula. Karena keberanian yang kini dimilikinya, Alice menolak tawaran tinggal di Wonderland. Ia tidak mau lari dari kenyataan dan berani menghadapi dunia nyata yang telah menunggunya.
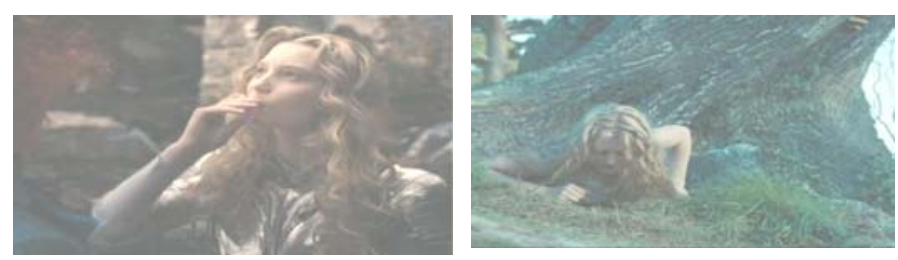

Gambar 26 Setelah misi selesai, Alice kembali ke dunianya

Sang hero menghadapi ujian sekali lagi, dan berhasil melaluinya. Karena ujian itu, ia seakan dilahirkan menjadi diri yang baru. Di dunia nyata, semua orang menunggu jawabannya atas lamaran sang pria kaya. Alice berani mengambil keputusan sesuai hati nurani. Ia menolak lamaran. Ia pun berani mengemukakan isi hati, menunjukkan jati dirinya tanpa tertekan oleh tuntutan masyarakat.
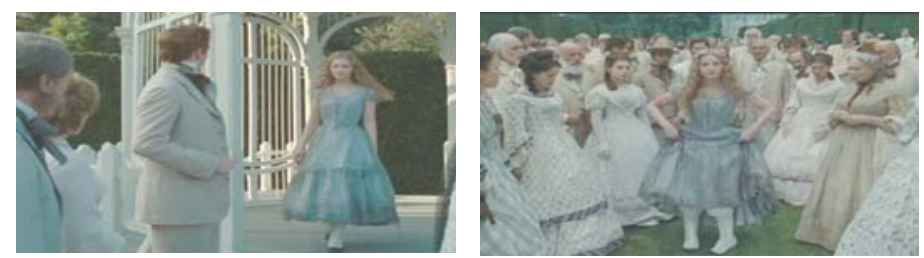

Gambar 27 Alice di dunianya 
Sang hero lengkap dengan sesuatu berharga yang telah ia temukan kembali ke kehidupan semula atau melanjutkan perjuangannya. Alice menentukan langkah hidupnya sendiri; meneruskan usaha ayahnya.

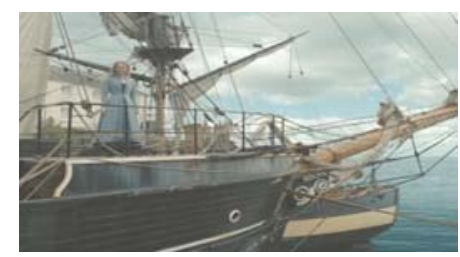

Gambar 28 Alice meneruskan usaha ayahnya

Struktur cerita Alice in Wonderland sangatlah tertata. Karakter utama yang penuh masalah melakukan petualangan yang membawanya pada penyelesaian masalah. Penonton pun dapat dengan jelas menangkap pesan-pesan yang ingin di sampaikan film ini.

Berdasarkan contoh penerapan yang telah disajikan, artikel membahas beberapa alasan pentingnya penerapan teori struktur cerita. Alasan tersebut antara lain: (1) struktur cerita membantu menyusun cerita lebih fokus. Dengan menerapkan teori struktur cerita diharapkan masalah yang diangkat, cara penyelesaian, dan pesan yang ingin disampaikan sebuah film dapat dikomunikasikan lebih baik pada penonton; (2) struktur cerita membantu menyusun cerita yang lebih dinamis, dan dramatis.

Semua teori di dunia selalu diiringi dengan pro dan kontra, begitu pula teori-teori struktur cerita ini. Namun berikut beberapa poin yang diharapkan dapat meminimalisir pandangan negatif pada teori-teori struktur cerita. Teori struktur cerita bukanlah formula baku melainkan peta panduan untuk menyusun cerita. Teori ini hanya menyediakan kerangka cerita, tapi bagaimana cara mengisi kerangka itu, semua tergantung kreativitas yang dimiliki tiap individu. Bukannya mengekang, justru struktur ini yang membantu mengarahkan, mengolah dan memancing kreativitas. Masih merasa terbatasi secara kreativitas? Kuasailah teori-teori dasar ini dan langgarlah! Berekperimen dan ciptakan berbagai teori baru. Selain itu, hampir semua film box office menerapkan salah satu dari teori struktur cerita film. Apakah itu membuat film-film itu kehilangan nilai orisinalitas? Rasanya tidak. Orisinalitas dapat timbul dari berbagai hal, misalnya: keunikan masalah yang diangkat, karakter, orkestrasasi pengadenganan, dan lain sebagainya.

\section{PENUTUP}

Ada beragam teori struktur cerita. Tapi pada prinsipnya semua bertujuan sama yaitu membantu menyusun cerita yang fokus, dan dinamis. Teori-teori ini tidak bermaksud membatasi kreativitas, melainkan memancing, membantu mengarahkan dan mengolah kreativitas. Dengan menguasai teori-teori struktur cerita dasar, barulah dengan mudah dapat menciptakan cerita film eksperimental, out of the box, atau bahkan menciptakan teori-teori baru. Dengan menerapkan teori struktur cerita, diharapkan industri perfilman dapat menghasilkan film-film yang kuat secara cerita dan dapat mengkomunikasikan pesan dengan lebih baik. 


\section{DAFTAR PUSTAKA}

Campbell, J. (2008). The hero with a thousand faces. California: Novato.

Field, S. (1984). Screenplay: The foundations of screenwriting. New York: Bantam Dell.

\section{RIWAYAT PENULIS}

Angela Oscario lahir di kota Semarang pada 14 Januari 1985. Penulis menamatkan pendidikan S1 di Universitas Bina Nusantara dalam bidang desain komunikasi visual pada tahun 2007. Penulis aktif mengajar di Universitas Bina Nusantara pada jurusan desain komunikasi visual sejak tahun 2010. 